\title{
DEVELOPING DIFFERENTIATED ELECTRONIC SUPPLEMENTARY READING EXERCISE FOR THE SLOW LEARNERS OF SEVENTH YEAR STUDENTS AT SMP N 2 SINGARAJA
}

\author{
Dinata, K.A.A. \\ English Education Department, Ganesha University of Education \\ e-mail: andiarta@gmail.com \\ Nitiasih, P.K. \\ English Education Department, Ganesha University of Education \\ e-mail: titiekjegeg@gmail.com \\ Mahayanti, N.W.S. \\ English Education Department, Ganesha University of Education \\ e-mail: surya.mahayanti@undiksha.ac.id.
}

\begin{abstract}
Self-regulated learning (SRL) becomes one of the crucial skill in nowadays era. The ability to regulate their own learning, helps students to achieve better. In order to prove that, this study aimed at investigate the correlation between SRL strategies and the student's English achievement by using expost facto research design. 152 students were involved to be the sample of this study and asked to fill Motivated Strategies for Learning Questionnaire (MSLQ) developed by Pintrich (1991) as the data of their SRL strategies. For the achievement, the record keeping document were used. As the result, it was found that there is a significant correlation between SRL strategies and the student's English achievement.
\end{abstract}

Key words: self-regulated learning strategies, English achievement.

\section{INTRODUCTION}

Being good students in this era mean not to be passive and dependent individuals. It means that in order to succeed in learning, learners should be active and responsible for their own learning. Ideally, students in this present globalization era should organize and construct their prior knowledge with the newly received information (Perkins,1992). Perkins (1992) stated that it is a crucial role of teacher to be facilitator to give chance for students constructing their knowledge. Thus, it is not only the teacher's authority to design the teaching and learning process, such as determining the activities that should be done in the classroom, providing the educational materials, or even setting the context for learning. It is also the learners' responsibility to decide it. Teachers must be able to give the learners opportunity to build their awareness in learning, so the learners will have better ways to regulate their learning which can improve their learning quality and also their achievement at the end.

In regulating their learning, each student will have different strategies. Setting the goals, monitoring the process of their learning, controlling their behaviour and motivation are things that they have to manage by themselves as independent learners. 
Those active constructive process done by the students is called as self- regulated learning (Pintrich, 2003). When learners become metacognitively, motivationally, and behaviorally active participants in learning, they regulate their selves in learning. In order to achieve an academic goal, in self-regulation processes, there are self-directed feelings, thoughts, and also behaviour. The students or the learners can modify, sustain, and instigate their goal-directed actions which are part of self-regulated learning. The students can practice this strategy for their academic studies (Zimmerman, 1989).

Zimmerman (2002) argued that self-regulated learning is an activity which is proactively made by the learners, means that they are aware of their strength and limitations. In this process, the learners' mental capability can be changed into educational aims. In doing self-regulated learning, the learners should have the skill how to learn effectively, starting from setting the goal of their learning, having a specific plan to attain it, monitoring their performance and behavior, enhancing the motivation, continuing to use the effective strategies, reflecting the progress, and evaluating the results (Schunk \& Ertmer, 2000). Pintrich and DeGroot (1990) stated that motivational strategies and learning strategies are two important aspects of selfregulated learning. Strategies that are used by the students to cope with stress and emotions which sometimes generated when they tried to overcome failures and become good learners are called motivational strategies. However, learning strategies are some methods used by the students to improve their understanding, integration, and retention of new information in the learning process. Pintrich (1995) stated that selfregulation is not a personality trait, so the learners can control their behaviour and affect to improve their academic learning and performance. Thus, self-regulated learning can improve the learner's problem-solving skill which can give some effect on their academic achievement. Blumenfeld\& Marx (1997) mentioned that self-regulated learning requires both will and skill in order to achieve the academic goals. For this reason, education must help the learners to be aware of their thinking, strategic, and direct their motivation toward valuable goals.

An observation was conducted in one Senior High School in rural area in Bali in order to see the phenomenon related with strategies in regulating learners' learning. From the observation, it was found that the students show positive interest in learning English. They also show some characteristics of self-regulated learners such as, how they are taking note during the class to make their learning more organized which is part of organization strategy and to be able to learn the material after the class was over which is part of rehearsal strategy. They also show how to learn in peer and sometimes seeking for help to their partner and also to their teacher if they have some obstacle in understanding the material.

Considering the phenomenon above, this study investigated the correlation between self-regulated learning strategies used by the 10th grade students at and their English achievement. Besides, this study identified the most self-regulated learning strategies used by them. Some previous researches regarding with self- regulated learning strategies have been conducted by Sardareh et al. (2012) and Inan (2013). They took the university students as the sample while study in high school level related to this topic is still limited.

\section{METHOD}

International Journal of Language and Literature | 26 
The study was conducted by using an ex-post facto research design using correlational study to know: (1) the correlation between self-regulated learning strategies (X) and the 10th grade student's English achievement (Y); (2) to identify the most self-regulated learning strategies used by the 10th grade students. The population of this study are 241 students from all the 10th graders in which the simple random sampling was used to determine the samples which were 152 students.

There were two variables which were investigated in this study, Self-regulated learning as independent variable and English achievement of the student's as the dependent variable. The data of the study were collected in two ways namely by distributing questionnaire and record-keeping document. The questionnaire used in this study was adopted from the Motivated Strategies for Learning Questionnaire (MSLQ) developed by Pintrich (1991) for self-regulated learning strategies. For learning strategies scale, there are 9 dimensions, such as, (a) rehearsal, (b) elaboration, (c) organization, (d) critical thinking, (e) metacognitive self-regulation, (f) time and study environment, (g) effort regulation, (h) peer learning, and (i) help seeking. The validity of the questionnaire was conducted to make sure that all the items in the questionnaire are valid. Pearson Product Moment Correlation was used to analyse the validity of the instrument. In analysing the data, two kinds of testing were conducted, Prerequisites Test (including normality test and linearity test) and Hypothesis Testing

\section{FINDING AND DISSCUSSION}

The Correlation between Self-regulated Learning and English Achievement

Since this study aimed at finding the relationship between the self regulated learning as independent variable (X) and academic achievement in English subject as dependent variable (Y), the hypotheses of the study were analyzed by using Pearson Product Moment Correlation. There are some requisites needed to be fulfilled as following:

Table 1. The Result of Normality Test Using Kolmogorov-Smirnov test

\begin{tabular}{l|c|c|c|c|c|c}
\multirow{2}{*}{} & \multicolumn{4}{|c|}{ Kolmogorov-Smirnov } & \multicolumn{3}{c}{ Shapiro-Wilk } \\
\cline { 2 - 8 } & Statistic & df & Sig. & Statistic & Df & Sig. \\
\hline SRL & 129 & 152 & .000 & .942 & 152 & .000 \\
\hline English Achievement & .223 & 152 & .000 & .877 & 152 & .000
\end{tabular}

Table 1 shows that the self-regulated learning strategies of the students did not have the normal distribution, since the sig. value of all variables were lower than 0,05 ( $<0.05)$. Therefore, the non-parametric test (Spearman's rho) was conducted to know the correlation between students' self-regulated learning strategies and their English achievement.

However, linearity test of data was conducted to know the relationship between each variable. It was done by testing the regression line from the independent variables to the dependent variables. SPSS 16 program was used to conduct the linearity test of data which the result can be seen on the ANOVA table by looking at the Fderivation of linearity. The result of linearity test can be seen in the following table.

Table 2 The Result of Linearity Test of Data 


\begin{tabular}{l|l|l|l|l|l} 
No & $\begin{array}{c}\text { Dependent } \\
\text { Variable }\end{array}$ & $\begin{array}{c}\text { Independent } \\
\text { Variable }\end{array}$ & $\begin{array}{c}\text { Deviation from } \\
\text { Linieraty }\end{array}$ & Linearity & $\begin{array}{l}\text { Interpret } \\
\text { ation }\end{array}$ \\
\hline 1 & $\begin{array}{c}\text { English } \\
\text { Achievemen } \\
\mathrm{t}\end{array}$ & $\begin{array}{l}\text { Self-Regulated } \\
\text { Learning Strategies }\end{array}$ & 0.013 & .000 & Linier \\
& & & &
\end{tabular}

The coefficient of F-deviation f linearity was used to determine the linearity test of data. The data is linear if the coefficient of F-deviation is higher than 0.05 , and the line of regression is meaningful if the coefficient of F-deviation of linearity in ANOVA table is less than 0.05. The result of the linearity test of the data shows that the significant value of Deviation from linearity was higher than 0.05 and the sig. value of linearity was lower than 0.05 which means that the relationship between the dependent and independent variable was linear.

After that, the hypothesis in this study was conducted in order to know whether there is a significant correlation between self-regulated learning strategies and the 10th grade student's English achievement or not. The data were processed using SPSS 16 program. The non-parametric statistical test, Spearman's Rho correlation was conducted to test the hypothesis. The result can be seen in the following table.

Table 3 The Correlation between Self-regulated Learning Strategies (X) and English Achievement (Y)

Correlation

\begin{tabular}{l|l|l|l|l}
\hline \multirow{3}{*}{ Spearman's rho } & \multirow{2}{*}{ SRL } & & SRL & $\begin{array}{l}\text { English } \\
\text { Achieveme } \\
\text { nt }\end{array}$ \\
\cline { 3 - 5 } & & Correlation Coefficient & 1.000 & $.566^{* *}$ \\
\cline { 3 - 5 } & Sig. (2-tailed) &. & .000 \\
\cline { 3 - 5 } & $\mathrm{N}$ & 152 & 152 \\
\cline { 3 - 5 } & \multirow{2}{*}{$\begin{array}{l}\text { English } \\
\text { Achieveme } \\
\text { nt }\end{array}$} & Correlation Coefficient & $.566^{* *}$ & 1.000 \\
\cline { 3 - 5 } & Sig. (2-tailed) & .000 &. \\
\cline { 3 - 5 } & $\mathrm{N}$ & 152 & 152 \\
\hline
\end{tabular}

**. Correlation is significant at the 0.01 level (2-tailed).

Based on table 3 above, it can be seen that by using spearman's rho correlational, a statically significant correlation was found between students' selfregulated learning strategies and their English achievement ( $\mathrm{rs}=0.566,=0.000)$ with the level of significance $(=0.01)$ which means that the null hypothesis was rejected.

The result shows that there is significant correlation between self-regulated learning strategies (X) and English achievement (Y). It can be said that the students who regulate their learning tend to have a better English achievement. 

Students

The Most Frequent Self-regulated Learning Strategies used by the 10th Grade

After finding that there is a significant correlation between self-regulated learning strategies $(\mathrm{X})$ and English achievement $(\mathrm{Y})$, the analysis was continued to find out the most frequent self-regulated strategies used by the students. The result of the analysis can be seen in table 4 bellow.

Table 4 Descriptive Statistics of Each SRL Strategies

\begin{tabular}{l|c|c|c}
$\begin{array}{c}\text { Self-Regulated Learning } \\
\text { Strategies }\end{array}$ & $\begin{array}{c}\text { Total } \\
\text { Items }\end{array}$ & Mean & Score \\
\hline Rehearsal & 3 & 14.66 & 4.886667 \\
\hline Elboration & 6 & 30.03 & 5.005 \\
\hline Organization & 4 & 19.64 & 4.91 \\
\hline Critical Thinking & 5 & 24.86 & 4.972 \\
\hline $\begin{array}{l}\text { Metacognitive } \\
\text { Regulation }\end{array}$ & 9 & 45.52 & 5.057778 \\
\hline Time \& Study Environment & 4 & & 5.1125 \\
\hline Effort Regulation & 3 & 20.45 & 4.593333 \\
\hline Peer Learning & 3 & 13.78 & 5.27 \\
\hline Help Seeking & 3 & 15.81 & 5.21
\end{tabular}

Table 4 shows all the self-regulated learning strategies with their total items and mean score. By calculating the mean and the total items, the score of each items are identified which is the biggest score means the most frequent strategies which is used by the students. From the table it shows that the most self-regulated learning strategies which is used by the students is peer learning strategy with the score 5.27 , followed by help seeking, time and study environment, metacognitive self-regulation, elaboration, critical thinking, organization, rehearsal, and effort regulation.

Self-regulated learning is about how and why the learners involve themselves in the learning process. It refers to the degree in which the learners are metacognitively, motivationally, and behaviorally active participants in their learning process. It is the reason why the students should understand well about themselves and some aspects related to their academic achievement (Zimmerman, 1989). In line, Pintrich et al. (1991) states that self-regulated learning strategies are the students' use of different cognitive and metacognitive strategies, and their management of different resources. Cognitive and metacognitive strategies covers: (1) rehearsal, (2) elaboration, (3) organization, (4) critical thinking, and (5) metacognitive self-regulation, while resource management strategies covers: (1) time and study environment, (2) effort regulation, (3) peer learning, and (4) help-seeking.

After analyzing the data, it can be assumed that those students in that school who are able to regulate their learning by using certain strategies tend to have best English achievement or score in the English subject. That result support the idea proposed by Zimmerman (1989) who states that all learners are responsive to some degree during instruction. However, the learners who have initiative, intrinsic motivation, and personal responsibility achieve particular academic success. These 
learners who can regulate their learning by their own are distinguished by their systematic use of metacognitive, motivational, and behavioral strategies, by their responsiveness to feedback regarding with the effectiveness of their learning, and by their self-perceptions of academic accomplishment.

Being able to regulate makes the learners mastering their own learning. It means that the students emphasize the importance of personal responsibilities in controlling the knowledge and the skills that already achieved. The self-regulated perspective in learning and also achievement are not only distinctive but it also has an implication on how the learners interact with their teachers and how the way the school should organize (Zimmerman, 1989). As mentioned by Slavin (2009) that in the 21st century, there are so many complex issues such as how the people switch their occupation because of some reasons, the learners failed to achieve their learning goal, the learners feel frustrated because of the homework they get in school, demand some new approaches and strategy which must be directed by the learners itself. Nowadays, one of the goals of education is to make the learners not to depend on the teachers anymore, so they can learn by themselves more intense, which means that they should become self-regulate learners.

Inan (2013) also found out that there was significant positive correlation between self-regulated learning strategies and Grade Point Average of the participants which means that self-regulated learning strategies play important role to improve students' achievement. As additional, the result of this study also supports the study conducted by Sardareh et al. (2012) in which the study aimed to investigate the relationship between self-regulated learning strategies and academic achievement in pre-university EFL learners. The result of the study shows that there was strong relationship $(r=.80)$ between the use of self-regulated learning strategies and students' English achievement.

Knowing that there is a significant correlation between self-regulated learning strategies and students' English achievement, it is needed to know which of the strategies is mostly used. The most frequent self-regulated learning strategies used by the students is peer learning strategy. Topping (2005) defines peer learning as the acquisition of knowledge and skills through active helping and supporting among status equals or matched companions. There was an assumption that peer helpers should be amongst the best students in the classroom. However, there are some differences of the student's ability and interest is certain situation that could prove that under-stimulating for the helper, who was unlikely to gain cognitively from the interactions. Peer learning can be occurred when there are some students of the same levels working together or students of varying learning levels working together.

There are some benefits which the learners receive from peer learning such as academic benefits, benefits to teachers through increased learner's engagement, social and behavioral benefits, effectiveness for varying learning levels of learners, and attitude on school and learning (Olmscheid, 1999). It is supported by Pintrich (1991) who states that collaborating with peers while studying has been found to have positive effects on achievement. When the learners talk to their peers, it can help them to clarify course material. Peer learning allow the teacher to provide the learners opportunity to be actively engaged in learning at the same time, and each learners be able to working on their own specific level.

The communication skills between the helper and helped is crucial in peer learning process. One learner must be able to give the explanation about the certain 
concept to another student very well in order to make them understand the concept. Listening, explaining, questioning, summarizing, speculating, and hypothesizing are all the valuable skills which should be transferable during peer learning process. In peer learning process, the enthusiasm, competence, and possibility of success of one student can make an influence on self-confidence of the other student (Topping, 2005). He adds that in peer learning process, all the learners have the chance to participate and to help, which make them feel valuable and worthwhile. In certain situation, one student who is helped in one subject is simultaneously helpers to students in a lower grade in the same subject. Then those who are helped in one subject may have a role as a helper to other learner in another subject. Here the teachers have an important role to support the peer learning of the learners which can develop their learning quality and learning outcomes. Peer learning build on individual's strength and mobilizes them as participants in the learning process.

The result of this study is quite different compare with Banisaeid \& Huang (2015). They found that the most self-regulated learning strategies used by the Chinese EFL Learners are effort regulation strategy, then followed by time \& study environment, organization, peer learning, help seeking, rehearsal, elaboration, critical thinking, and metacognitive self-regulation. It can be caused by the difference of the students' mind set in China and in Indonesia. People in Indonesia tend to help each other while Chinese have more individual characteristics.

\section{CONCLUSSION}

After the result and discussion being presented previously, there are some conclusions of this study: (1) There is positive significant correlation between selfregulated learning strategies and English achievement of the 10th grade students with correlation coefficient was $0.566(\mathrm{rs}=0.566)$, statistical significant was 0.000 ( = 0.000 ), and the level of significance $(=0.01)$. It can be concluded that the students who are able to regulate their learning by implementing such strategies in learning tend to get better academic achievement in English subject; (2) The most frequent self-regulated learning strategies used by the 10th grade students is peer learning strategy, followed by help seeking, time and study environment, metacognitive self-regulation, elaboration, critical thinking, organization, rehearsal, and effort regulation; (3) From the results of this study, some suggestions addressed to the students, teachers, and further researchers. The students must be able to regulate their learning since the education in the 21 st century challenges them to be able to become active learners who are responsible for their own learning. By regulating their learning, the learners can set their learning goals, monitor their learning process, control their behavior and also be motiveted to get the better academic achievement. For Teachers, they must be able to motivate the students in their learning. The role of the teachers as a facilitator in the students learning is very important to give the students direction so they can improve themselves which make an impact on their academic achievement. Train the learners how to plan, evaluate, monitor their learning process, and organize the materials given. It is also important to improve the learner's activities outside the classrooms such as seeking peers, adult or teacher's assistance, to review their tasks or test. However, for further researcher, it is recommend to conduct the other studies about self-regulated learning by using the other theory besides Pintrich theory about self-regulated learning strategies which is used in this study. Theory proposed by Zimmerman (1989) can be used to know the student's self-regulated learning strategies that is consist of the 
cyclical process of self-regulated learning such as forethought phase, performance phase, and self-reflection phase.

\section{REFERENCES}

Banisaeid, M., \& Huang, J. (2015). The Role of Motivation in Self-Regulated Learning and Language Learning Strategy: In the Case of Chinese EFL Learners. International Journal of Applied Linguistics \& English Literature. 4(5), 36-43.

Blumenfeld, P. C., \& Mark, R. W. (1997). Motivation and Cognition. In H. J. Walberg \& G. D. Haertel (Eds.), Psychology and Educational Practice (pp. 79-106). Berkeley, CA: McCut-chan

Inan, B. (2013). The Relationship between Self-regulated Learning Strategies and Academic Achievement in a Turkish EFL Setting. Academic Journals, 8, 15541550. doi: 10.5897/ERR2013.1561.

Olmscheid, C. (1999). The effectiveness of peer tutoring in the elementary grades. Long Beach: CSU

Perkins, D. N. (1992). Technology Meets Constructivism: Do They Make a Marriage? Hillsdale, NJ: Erlbaum.

Pintrich, P. R. \& DeGroot, E. V. (1990). Motivational and Self-Regulated Learning Components of Classroom Academic Performance. Journal of Educational Psychology, 82(1), 33-40.

Pintrich, P. R., Smith, D. A. F., Garcia, T., \& McKeachie, W. J. (1991). A Manual for the Use of the Motivated Strategies for Learning Questionnaire (MSLQ). Michigan: Ann Arbor

Pintrich, P. R. (1995). Understanding Self-Regulated Learning. San Francisco, CA: Jossey-Bass.

Pintrich, P. R. (2003). A Motivational Science Perspective on the Role of Student Motivation in Learning and Teaching Contexts. Journal of Educational Psychology, 95, 667-686.

Sardareh, S. A., Saad, M. R. M., \& Boroomand, R. (2012). Self-Regulated Learning Strategies (SRLS) and Academic Achievement in Pre-University EFL Learners. California Linguistics Notes. 37(1), 01-35.

Schunk, D. H., \& Ertmer, P. A., (2000). Self-regulation and Academic Learning: Selfefficacy Enhancing Interventions. In M. Boekaerts, P. R. Pintrich, M. Zeidner (Eds.), Handbook of self-regulation. San Diego, CA US: Academic Press.

Slavin, R.E. (2009). Cooperative Learning (Teori, Riset, Praktik). Bandung: Nusa Media.

Topping, K. J. (2005). Trends in peer learning. Educational Psychology, 25(6), 631645.

Zimmerman, B. J. (1989). A Social Cognitive View of Self-Regulated Academic Learning. Journal of Educational Psychology, 81, 329-339.

Zimmerman, B. J. (2002), Be-coming a Self-Regulated Learner: An Overview. Theory into Practice, 41, 64-70 